\title{
DOSSIÊ
}

Sociologias, Porto Alegre, ano 4, no 7, jan/jun 2002, p. 82-121

\section{A voz do usuário no sistema hospitalar: ouvidorias*}

LUIZA HELENA PEREIRA $A^{\star \star}$

\section{Introdução}

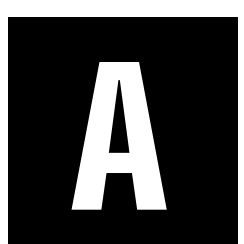

o longo dos anos noventa, novas políticas gerenciais foram implantadas no Brasil por alguns hospitais públicos, resultando na criação de serviços de ouvidoria. A análise de sua instalação desperta vários questionamentos. Que fatos moveram as instituições a criar um serviço deste tipo? Q uais os impactos institucionais e sociais do trabalho desencadeado pelo mesmo?

$N$ as duas últimas décadas, observou-se que o sistema de saúde brasileiro passou por reformas que determinaram o redimensionamento das políticas públicas no âmbito nacional, estadual e municipal, com repercussões nas instituições prestadoras de serviços. Algumas dessas políticas resultaram na criação de serviços de ouvidoria (SO ), serviços de atendimento ao cliente (SAC) ou de centrais de atendimento ao usuário (CAU), implantados em alguns órgãos governamentais e em instituições públicas e privadas. Em órgãos governamentais da área da saúde, esses serviços foram instalados em ministérios e secretarias estaduais e municipais. No caso de instituições prestadoras de serviços, constatou-se que hospitais públicos e privados estabeleceram suas próprias políticas gerenciais que, embora internamente definidas, acompanharam as propostas nacionais para a área da saúde.

As ouvidorias hospitalares passaram a acolher as reclamações dos usuários sobre 0 atendimento prestado. Estas tinham um caráter eminentemente social, pois questionavam situações que remetiam ao Sistema

* Este artigo toma por base os resultados da pesquisa "O uvidoria hospitalar: disciplinamento e envolvimento como estratégias rumo à democratização", realizada como tese de doutorado da autora, defendida em dezembro de 2000 , junto ao Programa de Pós-graduação em Sociologia do IFCH/UFRGS.

** Professora do Departamento de Sociologia da UFRGS. 
Sociologias, Porto Alegre, ano 4, no 7, jan/jun 2002, p. 82-121

Ú nico de Saúde (SUS) quando se tratava de hospitais públicos e ao tipo de serviço ofertado pelos hospitais e seus profissionais. Concebendo as reclamações como resultantes de relações sociais, mesmo quando permeadas pela técnica, como é o caso no âmbito médico-hospitalar, buscou-se compreender o significado dessas relações.

0 objetivo deste artigo é o de revelar a proposta teórica e os resultados da investigação sobre os motivos e as repercussões da criação de ouvidorias no âmbito de dois hospitais públicos. 0 estudo que serviu de base ao artigo examinou as ouvidorias de dois hospitais públicos de Porto Alegre, entre 1990 e 1998. O Hospital Fêmina criou, em 1990, um serviço de ouvidoria. O Hospital de Clínicas de Porto Alegre organizou, em 1994, um sistema de ouvidoria.

Buscou-se captar a organização de cada ouvidoria. Para tanto, foi efetuado inicialmente o levantamento de todas as reclamações registradas nas duas ouvidorias (268 no Hospital Fêmina e 849 no Hospital de Clínicas). Esta estratégia se impôs pelo fato de que, através da análise de todas as reclamações foi, possível mapear as áreas, os profissionais e os tipos de problema que levaram os usuários a registrarem uma queixa na ouvidoria. Para a pesquisa, esse mapeamento foi fundamental, pois, através dele, pode-se: 1) conhecer os usuários reclamantes e assim verificar quais as estratégias de envolvimento e de disciplinamento desencadeadas em relação aos mesmos; 2) conhecer os trabalhadores em saúde reclamados e evidenciar as estratégias de disciplinamento e de envolvimento a que foram submetidos e 3) acompanhar o percurso institucional das reclamações. As reclamações indicavam as relações que se estabeleceram entre instituição, usuários e trabalhadores em saúde. Para completar as informações, foram realizadas entrevistas com os agentes que participaram da experiência com as ouvidorias hospitalares, contemplando, assim, a análise qualitativa da pesquisa.

Para expormos os resultados da pesquisa inicialmente situamos 1) o surgimento dessa nova forma de gestão, no contexto da sociedade brasilei- 
ra, destacando como temas convergentes: a instituição hospitalar, sua relação com as propostas formuladas por ocasião da reformulação do Sistema Ú nico de Saúde (SUS) e as inovações gerenciais implantadas por essas instituições, face ao novo sistema.

A seguir, a partir do referencial teórico sobre o tema, apresentam-se as três dimensões construídas para a análise: 2) o interesse dos hospitais em implantar ouvidorias; 3) o impacto de seu trabalho, destacando as relações institucionais de envolvimento e disciplinamento de usuários e de trabalhadores em saúde e 4) os efeitos institucionais e sociais provocados pela ação das ouvidorias. Concluímos afirmando que as ouvidorias hospitalares são canais que podem democratizar as relações institucionais.

\section{O contexto do surgimento de ouvidorias hospitalares no Brasil}

\section{O s hospitais e as propostas de reformulação do SUS}

No Brasil verificou-se, nas últimas décadas, uma crise que afetou os sistemas de previdência social e de saúde e levou à necessidade de reforma desses sistemas. A partir da década de oitenta, o sistema de saúde passou por reformas que determinaram e resultaram em políticas públicas de saúde nos níveis nacional, estadual e municipal. Em relação aos hospitais, a crise estava a demonstrar a inviabilidade do modelo de saúde implantado a partir da década de setenta. A característica marcante desse modelo foi a penetração do capital privado na prestação de serviços de saúde, que expandiu sua cobertura populacional. 0 crescimento deste setor deu-se, principalmente, através da contratação de serviços hospitalares privados pela previdência social. Gerou-se assim uma distorção no sistema, pois essa expansão não significou um modelo mais equânime de atendimento, mas o contrário.

A crise foi um dos fatores que conduziu a sociedade civil a lutar por reformas mais profundas no sistema de saúde e a propor medidas 
racionalizadoras do mesmo. Os projetos para a implementação de mudanças no sistema vigente, na década de oitenta, corresponderam a diferentes propostas para viabilizá-las. Abarcaram as unidades gestoras, desde o sistema nacional até secretarias estaduais e municipais. As políticas e propostas repercutiram em instituições prestadoras de serviços de saúde, como os hospitais.

Duas propostas, entre outras ${ }^{1}$, para alterar o sistema então vigente, são explicitadas na sociedade brasileira. U ma, de caráter reformador sanitarista propondo racionalização, democratização, eqüidade e universalidade no atendimento à saúde. O utra, de caráter liberal propondo também a racionalização, mas buscando atender à lógica do capital, do mercado e da fórmula custo/benefício (Melo, 1993; Teixeira, 1989). Consideram-se, no presente trabalho, as duas primeiras propostas e, de acordo com a literatura sobre o tema, representada pelos estudos de Campos (1992), Melo (1993), Oliveira e Teixeira (1986), Paim (1989) e Teixeira (1989), entre outros autores, chama-se a primeira de projeto reformador e a segunda de projeto liberal.

A disputa para tornar hegemônica uma das propostas mostrou, por ocasião da Assembléia Nacional Constituinte em 1987, a polarização dos interesses diversos das forças sociais e definiu dois grupos na arena política. De um lado, os produtores dos serviços de saúde: a Federação Brasileira de Hospitais (FBH), a Associação Brasileira de Medicina de Grupo (ABRAM GE) e a Associação Brasileira das Indústrias Farmacêuticas (ABIFARMA) defendiam o projeto liberal, criticavam o caráter estatizante e integralizador das ações de saúde, apontando para a marginalização da iniciativa privada e sugeriam medidas racionalizadoras e liberais.

De outro lado, setores dos trabalhadores e usuários da saúde defendiam a reforma sanitária. Entre estes, encontravam-se a Associação Médica Brasileira (AMB), na época expressando o Movimento de Renovação

1 Gastão Wagner de Sousa Campos (1992), por exemplo, aponta para a existência de três propostas: o projeto neoliberal, o projeto do SUS e o projeto racionalizador, este último originado nos quadros técnicos da administração pública. Nesta pesquisa consideraram-se mais significativas as duas primeiras propostas. 
M édica, o Departamento Intersindical de Estudos e Pesquisas de Saúde e dos Ambientes de Trabalho (DIESAT) e a Associação Brasileira de Pós-graduação em Saúde Coletiva (ABRASCO). Criticavam os planos, afirmando que contemplavam apenas 0 aspecto de racionalização do modelo vigente e não apresentavam políticas de saúde. Salientavam ainda a necessidade da participação do usuário, apontando criticamente a contenção de gastos governamentais para os setores sociais e o privilegiamento do grande capital na assistência médica.

A proposta reformadora do sistema de saúde trouxe à tona a rediscussão de várias questões presentes ao longo da história do setor da saúde no Brasil, explicitadas por Luz em suas Notas sobre as políticas de saúde no Brasil de transição democrática (1991). Entre estas, encontramse as propostas que viriam a se constituir nos princípios do SUS: a unificação institucional, a hierarquização, a descentralização dos serviços de saúde e a participação popular. Incorporou a reivindicação de medidas racionalizadoras, mas estas situavam-se na lógica epidemiológica de atendimento das necessidades coletivas, portanto, sociais. Como resultado deste debate emergiu uma indagação de caráter mais amplo sobre a sociedade brasileira, em termos de democracia e de direitos humanos. Expandindo a concepção de saúde, enfatiza-se que esta deve contemplar as condições sociais de existência, como mencionaram Augusto e Costa (1993).

A proposta liberal procurou garantir a posição da iniciativa privada no processo que implanta a reformulação do sistema. Enfatiza a racionalização, mas dentro da lógica da lucratividade e do mercado. Argumentava pela redução dos custos no setor saúde a partir do discurso neoliberal da diminuição do tamanho do Estado e da privatização das ações de saúde.

0 movimento por alterações no Sistema Nacional de Saúde objetivouse concretamente nas Conferências Nacionais de Saúde, em 1986, 1992 e 1996; na Nova Constituição Brasileira, em 1988 e na Lei do SUS, em 1990. Na nova Constituição Federal é aprovado o SUS, cujos princípios básicos, orientadores das ações e dos serviços na área da saúde, são: a 
descentralização, 0 atendimento integral, a hierarquização através de uma rede regionalizada, a universalidade do atendimento e a participação da comunidade (Constituição Federal, 1995, seção II). A participação na gestão do SUS é regulamentada em lei e se dará através das Conferências e dos Conselhos de Saúde, estes com poder deliberativo (Lei № 8.142 de 28 de dezembro de 1990).

A partir dessa conjuntura, vêm à tona diferentes proposições para a redefinição dos serviços de saúde com vistas à adequação ao novo processo. Especificamente em relação ao hospital foi sugerido, na 9a CNS em 1992, que o mesmo passasse a ser um centro de promoção das ações de saúde e não, apenas um lugar de internação de pessoas doentes (Czapski, 1992, p.155). Surgem, também, propostas inovadoras de gestão definidas internamente por alguns hospitais. U ma delas foi a criação de serviços de ouvidoria.

\section{O uvidorias hospitalares como estratégia de gestão}

As características dos hospitais, no Brasil, correspondem àquelas configurações mais gerais que tornaram o hospital uma instituição de atendimento à saúde. As transformações pelas quais passou a instituição hospitalar a partir do século XVIII reorganizaram o hospital, implicando: 1) transformá-lo em uma instituição que promovesse a saúde; 2) sua organização em um espaço disciplinado; 3) o deslocamento do centro do poder para o médico; 4) modificá-lo para ser lugar de ensino e aprendizagem da prática médica; e ainda 5) torná-lo lugar de difusão do discurso médico que fundamenta os saberes e a prática médica. Estas transformações foram detalhadamente narradas por Foucault no seu texto 0 nascimento do hospital (1992) e no livro 0 nascimento da clínica (1994).

O hospital, fruto da sociedade moderna a partir do século XX, assume plenamente as características dessa sociedade. 0 cuidado médico prestado segue os parâmetros de uma organização empresarial, do tipo fábrica, norteado por normas técnico-científicas e requisitos de racionalidade, 
como lembra Trevizan, em sua análise sobre a administração hospitalar (1988). É a organização racional que, como Weber demonstrou em A ética protestante e o espírito do capitalismo (1967), penetra nas mais diversas áreas e relações sociais na sociedade moderna. Assim, o avanço da medicina científica e industrial permite o desenvolvimento de sofisticada tecnologia que, pelos seus altos custos, passa a ser centralizada nos hospitais. Estes se tornam centro da educação médica, de captação dos recursos e concentrador de tecnologia, resultando no modelo hospitalocêntrico. Nesse modelo, o hospital é a instituição central na prestação de atendimento em saúde. Ainda no decorrer do século XX, além das mudanças na estrutura organizacional e funcional do hospital, transformações de ordem externa também o afetaram diretamente. Conforme Trevizan (1988), entre as mudanças de ordem externa, podemos enumerar o surgimento de planos de pagamento antecipado pelos serviços hospitalares e maior preocupação dos governos com a qualidade de atendimento, com o financiamento e com a construção de hospitais.

No que se refere à administração da instituição hospitalar, salienta-se que, historicamente, algumas análises e práticas, no Brasil, buscam inspiração nas Teorias Clássicas da Administração, incorporando os princípios propostos por Taylor e Fayol ${ }^{2}$ para efetivar a administração gerencial. Atualmente técnicas da qualidade total (QT) e círculos de controle de qualidade (CCQ ) são implantados em hospitais e em outras instituições de saúde (Rigon, 1993; Seminário Discute, 1993). Esta abordagem corresponde, em nosso entender, ao que Winkler, citado por Hambleton, apontou como modelo de consumismo do tipo supermercado (p. 128) ${ }^{3}$ e se relaciona, em nosso país, ao projeto liberal para a área da saúde. Alguns hospitais que, após passarem por uma crise institucional e aderirem ao Programa da

2 Frederik W. Taylor escreveu seu tratado sobre os Princípios da Administração Científica no final do século XIX, nos Estados Unidos, propondo os princípios que deveriam nortear a administração de uma empresa, embasado na ciência positiva e racional. Henri Fayol, no começo do século XX na França, elaborou uma teoria para a Administração Industrial Geral com ênfase no gerenciamento de recursos humanos, também com base nesta ciência.

3 A expressão utilizada é "the supermarket model of consumerism", que expressa melhor a noção explicitada por W IN KLER, F. Consumerism in health care: beyond the supermarket model. Policy and Politics. September 1-8, 1987 apud H AM BLETO N, Robin. Consumerism, decentralization and local democracy. Public Administration. London, The Royal Institute of Public Administration, v. 66, p. 125-147, summer 1988. 
Qualidade Total, argumentaram ser esta uma forma encontrada para meIhorar a qualidade e ampliar a assistência e, assim, competir e atuar num mercado diferenciado, de convênios e particular, no qual o cliente tem a chance de escolher o serviço ${ }^{4}$.

0 modelo do tipo supermercado é fortemente criticado por alguns autores, entre os quais W inkler, pois provocaria mudanças na aparência e não na substância da prestação de serviços, afastando o conhecimento da situação real e da estrutura de poder vigente. A crítica de Winkler remete ao fato de que, numa relação de mercado, o consumidor tem realmente poder de escolha, e esta é pessoal. No caso dos serviços públicos, ao contrário, como prestam atendimento de caráter coletivo, devem prever, em sua estrutura, mecanismos de envolvimento dos seus usuários. Este modelo pode trazer contribuições, se adaptado para o setor público. Porém suas falhas ficaram demonstradas, segundo esse autor, no que diz respeito à redução da disparidade de poder entre usuários e provedores dos serviços públicos, fracassando ao tentar fortalecer a cidadania e o controle local, quanto à tomada de decisão sobre a provisão coletiva dos serviços. A principal objeção à adesão a este enfoque, no setor da saúde, além das acima citadas, é que o enfoque do consumismo trata de relações entre empresas e consumidores e não de direitos dos pacientes.

Temos no Brasil, como alternativa de gerenciamento público, propostas diferentes das recém-referidas apresentando outra concepção de gestão dos serviços de saúde, que também devem ser consideradas. TrabaIham com a idéia de radicalizar o processo de descentralização até cada unidade de saúde e até cada equipe multiprofissional e procuram ampliar a democratização gerencial através da gestão coletiva dos serviços de saúde, com a participação direta da comunidade.

Essas concepções vêm sendo desenvolvidas pela equipe do Laboratório de Planejamento e Administração (LAPA) e se encontram reunidas

4 Esta afirmação foi feita pelo Sr. Minotto, coordenador do Programa Q ualidade Total (PQT), da Santa Casa de M isericórdia de Porto Alegre, durante sua explanação, por ocasião do 230 "Benchmarking Concedido", em 26 de novembro de 1997. 0 "Benchmarking Concedido" é a apresentação ao público interessado do trabalho realizado e dos resultados alcançados, como forma de divulgar e ganhar a adesão ao programa de qualidade. 
nos vários trabalhos do professor e médico sanitarista Gastão Wagner de Sousa Campos, citados na bibliografia, entre outras publicações. Estão sendo implantadas, através de experiências concretas com assessoria do LAPA, conforme narrado em Inventando a mudança na saúde, livro organizado por Luiz Carlos Cecílio (1994). N a mesma concepção, insere-se o trabalho descrito em Promovendo a eqüidade: um novo enfoque com base no setor saúde, de Emanuel de Kadt e Renato Tasca (1993).

Essa abordagem, segundo nosso entender, tem a compreensão do processo de gestão como forma de descentralização administrativa e possibilidade de desenvolver a democracia local (H ambleton, 1988) e se relaciona, no Brasil, ao chamado projeto de reforma sanitária brasileiro.

Como forma de inovar a administração de instituições ocorreu, nas últimas décadas, a expansão de ouvidorias em vários países do mundo, difundindo-se na América Latina, assim como no Brasil. Nesses países foi implantada em setores governamentais e em instituições públicas e privadas. Alastrou-se nos vários campos sociais como o do direito, da administração, da comunicação e no campo da saúde. No Brasil, esse serviço foi instalado em órgãos e instituições públicas e privadas, como por exemplo: universidades, companhias jornalísticas, companhias telefônicas e hospitais.

No Brasil, a implantação de ouvidorias na área da saúde ocorreu em âmbito governamental e também institucional. Está associada à crise e às transformações verificadas nesta área, na década de noventa, pois as circunstâncias tornaram favoráveis, como vimos, propostas que indicaram a participação e o controle do cidadão sobre as atividades de prestação de serviços de saúde, assim como medidas de desburocratização. Estes princípios foram inseridos na Constituição Federal em 1988 e na lei do SUS, em 1990. Em 1996, a 10ạ CNS (Conferência Nacional de Saúde, 1997) emitiu parecer favorável à implantação de Ouvidorias no SUS, parecer que foi incluído no Relatório Final. Nesse relatório lê-se que: O s conselhos e Gestores do SUS devem constituir e implementar novos mecanismos de participação. Entre esses mecanismos incluem-se: Ouvidorias e serviços 
Disque-Saúde em todos os níveis do SUS, vinculados aos Conselhos de Saúde (p.35) e Os Gestores do SUS devem agilizar a criação das carreiras de Auditor em Saúde, bem como de O uvidor Público Hospitalar (p.56) ${ }^{5}$.

$\mathrm{Na}$ década de noventa no Brasil, ouvidorias foram reativadas ou implantadas nas estruturas administrativas públicas. No âmbito do governo federal, foi criado o programa chamado Disque Saúde, junto ao Ministério da Saúde. Nos níveis estaduais e municipais, constataram-se serviços de ouvidoria na Prefeitura de Curitiba e no governo do Estado do Paraná. Estes abarcaram as secretarias estaduais e municipais da saúde, atingindo também as instituições prestadoras de serviços. Esse programa e serviços foram criados para receber denúncias sobre problemas relativos ao atendimento à saúde da população $0^{6}$.

Alguns hospitais redefiniram suas práticas institucionais adotando novas formas de gerenciamento. Nasúltimas décadas, o hospital tornou-se, como vimos, figura central no sistema de saúde brasileiro para a prestação de serviços de atendimento à população, tanto que se enfatizou o modelo hospitalocêntrico como característica desse sistema. 0 atendimento hospitalar é realizado por dois tipos de hospitais; os públicos e os privados, sendo estes últimos em grande maioria. Nos dois tipos de hospitais, verificou-se, na década de noventa, acentuar-se as características empresariais.

o bservou-se, por exemplo, que alguns hospitais privados assumiram gradativamente formas de gestão similares às de uma empresa com fins lucrativos. As modificações que reorganizaram esses hospitais deram-se em termos de opção por um modelo de autonomia de recursos, frente ao sistema de saúde, através da utilização, em larga escala, de uma forma de

5 É importante definir o lugar da ouvidoria na proposta dos reformadores, de controle social sobre o SUS. Por estarem implantadas dentro da estrutura administrativa do hospital as ouvidorias têm como característica atender a demanda dos usuários. Nesse sentido são auxiliares na gestão de atenção à saúde. Tal mecanismo se diferencia dos conselhos - principal elemento estratégico de controle social para os reformistas - ao colaborar para a avaliação de serviços prestados, ao invés de atuar sobre o processo de decisão sobre como e qual tipo de atenção a ser oferecido. A ouvidoria não tem como pressuposto a organização prévia de usuários e a escolha de representantes que expressem sua discordância ou suas proposições. Por isso, nesses casos, não existe a possibilidade de participação do usuário, no sentido de tomar parte do processo de decisão política. No entanto eles podem vir a contemplar os setores mais frágeis da população, que sequer dispõem dos canais organizados de expressão política.

6 A primeira ouvidoria pública do país foi instituída em Curitiba, em 1986. Desativada após dois anos de funcionamento, volta a ser ativada em âmbito estadual, no Paraná, em 1991. O projeto Disque-Saúde do governo federal, proposto em 1993, passa a funcionar, efetivamente, em 1997. 
assistência que proliferou, no Brasil, nos últimos anos: os Planos de Assistência Privada. Os convênios, como são chamados, tornaram-se uma opção para as camadas médias da população. Esta faixa procurava não submeter-se à demora em conseguir atendimento através do SUS, mas também não tinha condições de pagar pelo atendimento particular. Assim, os hospitais privados passaram a oferecer atendimento principalmente através de convênios e de pagamento direto. Embora muitos deles sejam cadastrados junto ao SUS e ofereçam parte de seus leitos para o mesmo, atendem especialmente os pacientes particulares e conveniados por outros planos de saúde. Porém, a maior parte do financiamento desses hospitais continua vindo do SUS, como é o caso da Santa Casa de Misericórdia de Porto Alegre. Ao mesmo tempo, os hospitais privados implantam programas para a qualidade total e se tornam exemplares na qualidade de atendimento. Veja-se, em Porto Alegre, os exemplos dos Hospitais Moinhos de Vento, Mãe de Deus e Santa Casa de Misericórdia.

Por sua vez, alguns hospitais públicos, devido às precárias condições em que se encontravam passaram também a procurar alternativas para superar as dificuldades econômicas e manter uma qualidade de atendimento compatível com sua qualidade tecnológica, visto que alguns desses hospitais contam com a mais alta tecnologia no campo da saúde. Para tanto, utilizaram fórmulas similares às da iniciativa privada como a implantação de programas para a qualidade total.

Inovaram, porém, implantando outras estratégias, como os exemplos de ouvidorias hospitalares indicam. Estas foram inseridas na estrutura hospitalar, em alguns casos, ao mesmo tempo que os programas de qualidade total, mas não de forma tão generalizada quanto os últimos. Em instituições de saúde como hospitais um serviço de ouvidoria foi instalado, inicialmente no Hospital Hospital Fêmina de Porto Alegre em 1990 e, mais tarde, estendido para todo o Grupo Hospitalar Conceição, do qual o primeiro faz parte. Em Porto Alegre, também foi estruturado um sistema de ouvidoria no Hospital de Clínicas, em 1994. O utros hospitais públicos do 
país implantaram o serviço, como os hospitais de Hospital de Clínicas de São Paulo, em 1994, Universitário de Londrina, em 1992 e Municipal O dilon Behrens de Belo Horizonte, em 1995, entre outros?.

Concebendo instituições como relativamente autônomas (Foucault 1995 e 1992; Bourdieu, 1992 e 1994) frente às políticas ditadas pelo Estado, afirma-se que são também capazes de desenvolver políticas específicas de gestão. A decisão da implantação de ouvidorias foi tomada de forma autônoma pelas instituições pesquisadas. O uvidorias hospitalares são compreendidas como novas formas de gerenciamento porque esta experiência era inédita, no Brasil até a década de noventa. Argumenta-se que sua implantação foi uma das estratégias utilizadas pelos hospitais para adequar-se às transformações ocorridas na área da saúde.

Nessa medida, sua implementação apoia-se nas propostas liberal ou reformadora e possibilita, neste caso, a efetivação, no âmbito das instituições, dos princípios do SUS de democratização - envolvimento - e de desburocratização institucional - disciplinamento.

\section{O interesse dos hospitais em implantar ouvidorias}

A literatura sobre ouvidorias hospitalares é rara em nosso país. Da mesma forma, o tema do envolvimento e de disciplinamento de usuários e de trabalhadores, a partir da instalação de serviços de ouvidoria em hospitais, não foi estudado pelos investigadores no Brasil. Esta foi a pesquisa que desenvolvi na minha tese de doutoramento. Relacionar hospitais e ouvidorias possibilitou a compreensão de que as ouvidorias hospitalares, no momento atual, são um local privilegiado para se estudarem novas estratégias de gestão, bem como as estratégias de envolvimento e de disciplinamento em hospitais.

Considerou-se inicialmente que, como instituições relativamente autônomas (Foucault, 1995 e 1992; Bourdieu, 1992 e 1994), os hospitais

7 Nestes hospitais, porém, os serviços de ouvidoria pararam de funcionar após breve período de atuação, ou não chegaram a ser implantados, apesar da intenção em fazê-lo, como o de Alagoas, em 1992. 
decidiram de forma independente pela implantação de ouvidorias. Como micropolíticas, esta decisão pode estar restrita às instituições, sem que ocorram, necessariamente, transformações macro estruturais, ou sejam induzidas por estas.

Com efeito, a análise das ouvidorias dos hospitais Fêmina e Clínicas, abordada sob a ótica de micropolítica institucional, demonstrou a autonomia relativa dos mesmos em implantar suas próprias políticas. No Hospital Fêmina, a implantação do serviço de ouvidoria constituiu-se em uma micropolítica institucional sendo criado um setor autônomo com um cargo específico de ouvidor.

No Hospital de Clínicas, o sistema de ouvidoria não se constituiu como tal. Foi estrategicamente instalado no Grupo de Pacientes Externos (GPE), setor este responsável pela coordenação do ambulatório e da emergência, isto é, voltado para o atendimento dos pacientes externos do Hospital. Neste, o argumento, justificando o fato de não ter sido instalado como um setor autônomo, remeteu para a dependência do Hospital em relação ao governo central, para mudar organograma e alocar recursos para o novo setor.

Esta comparação permitiu destacar que, embora relativa, a autonomia das instituições pode dar-Ihes margem a uma atuação mais decisiva na implantação de ouvidorias e outras micropolíticas institucionais.

Entre os vários motivos que levam à opção pela voz destacam-se: administrar a incompetência de direções, o abuso de poder e a inépcia burocrática. Atualmente enfatiza-se uma mudança do principal propósito da instituição, que procura promover uma melhor administração e corrigir práticas incorretas, como expressou Hirschman em seu livro Saída, voz e lealdade, escrito em 1973.

As instituições instalam ouvidorias porque é uma das maneiras pelas quais a administração pode tomar conhecimento das falhas institucionais. Argumenta-se que, como toda instituição, também os hospitais investigados se deparavam com problemas de racionalidade, de ética ou de com- 
portamento funcional (Hirschman, 1973) quando da instalação de suas ouvidorias. Estes foram evidenciados nos diversos tipos de reclamações acolhidas. Elas indicaram, em relação ao primeiro problema, a necessidade de racionalizar a acolhida ao reclamante. Os usuários reclamavam de comportamentos não-éticos, como médicos sugerirem a cobrança de honorários para atendimento particular e, em relação ao terceiro problema, de grosseria por parte dos profissionais em atender aos usuários.

Um dos objetivos de instalação de uma ouvidoria hospitalar, coincidente nos dois hospitais, foi o de melhorar a gestão administrativa, aprimorando a qualidade de atendimento prestado pelas instituições através de seus profissionais. Antes da implantação das ouvidorias, havia muitas reclamações, e estas caíam diretamente na administração central, ou eram feitas a qualquer pessoa, à imprensa inclusive.

O s usuários manifestavam, assim, através das reclamações, aspectos deste funcionamento deficiente. Reclamar foi uma maneira de forçar as instituições a restaurarem seu bom funcionamento. Os hospitais foram obrigados a procurar uma forma de corrigir as causas dos problemas funcionais (Hirschman, 1973). A opção pela ouvidoria foi uma das formas encontradas para isso.

As ouvidorias hospitalares foram implantadas como uma das formas pelas quais os hospitais podiam auscultar os "dizeres" sobre a qualidade de seu atendimento. Constituíam-se, portanto, em modalidades institucionais para verificar as suas falhas. Essas falhas indicavam problemas estruturais e de funcionamento ${ }^{8}$. Os primeiros apontavam para dificuldades em conseguir a primeira consulta e a reconsulta, mas a solução não estava na alçada

8 O s dados sobre a situação dos hospitais, no momento da pesquisa, e o tipo de reclamações, acolhidas pelas ouvidorias, foram classificados como referindo aspectos da estrutura e do funcionamento dessas instituiç̧̃os. Utilizou-se o termo estrutura para agrupar os dados e as reclamações que indicaram como os hospitais estavam constituídos, tendo em vista seus objetivos (Durkheim, 1983). Sob essa classificação foram incluídos os dados que demonstravam a capacidade de atendimento. Q uanto ao tipo de problemas reclamados, as relações que se estabeleceram a partir desta estrutura diziam respeito a relações mais cristalizadas, pouco flexíveis, no sentido de modificação dos mesmos. Estes problemas, por sua vez, resultaram em reclamações quanto ao funcionamento dos hospitais. Utilizou-se o termo funcionamento para agrupar os dados e as reclamações que indicaram como estava sendo realizado o trabalho, no interior dos hospitais, envolvendo as relações sociais que os fazem funcionar (Durkheim, 1983). As reclamações relatavam problemas que envolviam relações sociais mais flexíveise dinâmicase, por terem estas características, apontaram para soluções que estão mais diretamente afetas ao âmbito dos hospitais. As reclamações indicavam as condições de atendimento nos hospitais, ou seja, como o mesmo se realizava e qual a qualidade desse atendimento. A classificação das reclamaç̃̃es em estruturais e funcionais e sua distribuição pelas áreas e profissionais permitiu constatar os problemas, extrapolando tempo e espaço, e realizar a comparação entre os hospitais pesquisados. 
da instituição. Este aspecto ultrapassa os limites dos hospitais, denotando a dificuldade de acesso ao sistema de saúde por parte dos usuários do SUS, dada a elevada demanda por esses serviços e a limitada capacidade de oferta instalada.

Os problemas de funcionamento remetiam para os procedimentos técnicos, principalmente médicos, de relacionamento e de comunicação. Assim, a ouvidoria hospitalar indicava formas institucionais possíveis de regulação de conflitos.

Trata-se porém de falhas reparáveis, que possibilitam dois tipos de mecanismos de recuperação: um através da concorrência e outro através de mecanismos alternativos. A recuperação através da concorrência é usada em situação de mercado em que há diversidade de preço e qualidade do produto. Quando não dispõe de mecanismos competitivos, ou para complementá-los, a instituição pode optar por mecanismos alternativos, como o dar voz ao usuário. A opção da saída é um mecanismo da economia enquanto a opção pela voz é essencialmente um mecanismo político, pois a voz é ação política por excelência (Hirschman, 1973). Pode acontecer também, quando não há opção de saída através de mecanismos de mercado, como é o caso de instituições públicas (que Hirschman chama de bens públicos), por exemplo saúde e educação, a voz ficar minimizada, isto é, não se ampliar.

Considerou-se que a implantação de ouvidorias foi uma opção dos hospitais em dar voz ao usuário e, portanto, um mecanismo alternativo e político, por excelência. Isso porque, para os usuários desses hospitais, pelo fato de serem eles públicos, a opção de saída através do mercado não se viabilizava, dada a sua condição socioeconômica. Esta condição foi observada pelo atendimento prestado pelas instituições aos usuários, na grande maioria do SUS, $98 \%$ no Hospital Fêmina e $91 \%$ no Hospital de Clínicas; foi constatada, nas entrevistas com os usuários, através da coleta de informações sobre renda e condições de moradia, indicadores da qualidade de vida da população (Augusto, 1993; Dallari, 1987, Cohn, 1991 e Minayo, 
1992). Foi confirmada, também, pela observação da situação habitacional no momento da entrevista. Assim, a opção dos hospitais pelas ouvidorias foi, em princípio, uma medida democratizante (Hirschman, 1973).

A escolha da instalação de ouvidorias hospitalares, mesmo quando tomadas de forma autônoma por parte de hospitais públicos, caracteriza, porém, estratégias que expressam relações de forças sociais. Para analisar os casos dos hospitais Fêmina e Clínicas consideraram-se como motivo para a implantação de ouvidorias, além dos propósitos dos hospitais em tomar conhecimento de suas falhas institucionais acima citados, a intenção das ouvidorias em atuar dentro dos parâmetros da proposta liberal qualidade total para os clientes ou da proposta reformadora do SUS - democratização e desburocratização institucionais.

Constatou-se que, nos dois casos, quer como uma micropolítica claramente definida, quer como um sistema instalado em outro setor, não estavam expressamente formuladas as concepções que orientariam a prática da ouvidoria: se de adesão ao modelo liberal, na área da saúde ou de adesão à concepção reformadora, proposta pelo SUS. Verificou-se que as ouvidorias atuaram de acordo com alguns dos princípios dos dois projetos, mesclando ações características dos mesmos. Elas agiram de acordo com 0 enfoque do consumismo e a proposta liberal (Winkler, 1987; Sashkin e Kiser, 1994) quando deram mais ênfase aos programas de qualidade, subordinando a ação das ouvidorias aos mesmos. Embora a ouvidoria possa fazer parte de um programa de qualidade, ela também tem existência própria, podendo ser direcionada para uma postura mais democratizante das relações instituição-usuários.

Agiram de acordo com o projeto reformador: mesmo sem formular expressamente a vinculação ao projeto reformador do SUS ao serem criadas as ouvidorias, os hospitais enquadraram-se no enfoque da descentralização, da desburocratização, da democratização e na proposta reformadora quando criaram um canal para ouvir o usuário (Campos, 1991; Cecílio; 1994; Hambleton, 1988 e Hirschman, 1973). 
Porém, embora levantando o argumento de que as ouvidorias funcionariam para desburocratizar a relação instituição-usuário, não houve uma clara definição, por parte das instituições hospitalares por este princípio. 0 princípio de desburocratização foi mencionado pelo Hospital Fêmina, mas dentro da concepção de uma empresa moderna e não de um hospital público. Com a implantação da ouvidoria, esse Hospital não conseguiu, porém, desburocratizar a relação entre a instituição e os usuários reclamantes, pois o caminho que os mesmos passaram a percorrer para registrar uma reclamação foi indicativo de que a burocratização persiste.

Nos dois hospitais foram designados médicos como ouvidores. No Hospital Fêmina, médicos dedicavam algumas horas de suas atividades profissionais para serem ouvidores. Nessas horas tinham como função específica ouvir os usuários reclamantes. No Hospital de Clínicas, o responsável pelo acolhimento e encaminhamento das reclamações foi o GPE. O coordenador do Grupo, um médico, acumulava esta função com a atividade de encaminhamento das reclamações. Não foi criada a função específica de ouvidor hospitalar. Como nos dois hospitais os ouvidores foram tradicionalmente médicos, concluiu-se que o poder-médico se sobrepõe ao dos demais trabalhadores da saúde, na escolha do ouvidor (Foucault, 1992; Carapinheiro, 1998).

Por fim, para dar visibilidade ao usuários reclamantes, destaque-se que os dados que caracterizaram o perfil do usuário reclamante foram coincidentes nos dois hospitais pesquisados. 0 reclamante foi o próprio usuário, residente em Porto Alegre e em sua grande maioria, foi a mulher que registrou a reclamação. A mulher reclamou enquanto usuária, mãe ou filha de pacientes. Importante ressaltar o fato de a mulher, usuária ou familiar, ser a reclamante.

No caso do Hospital Fêmina, especializado no atendimento à muIher, este fato poderia ser considerado "normal". Mas, como os dois hospitais têm características diferenciadas, o fato de a mulher ter sido também a reclamante no Hospital de Clínicas traz à tona outro aspecto: que a mulher desempenha um papel preponderante no tratamento à saúde. Esta evidência encontra respaldo teórico na literatura que ressalta a importância 
desta no tratamento à saúde, em diferentes sociedades e culturas9 (H elman, 1994 e Abel-Smith, 1994). No caso dos hospitais em estudo, ressalte-se que, por ser a mulher quem mais procurou as ouvidorias hospitalares, também foi mais envolvida e disciplinada que os demais usuários reclamantes.

Esses dados foram explicitados para situar a realidade institucional sobre a qual foram registradas reclamações de usuários dos hospitais. As diferenças institucionais implicaram atuações distintas das ouvidorias em promover estratégias de envolvimento e de disciplinamento dos usuários reclamantes e dos trabalhadores em saúde, bem como nos efeitos gerados a partir do acontecimento. Foi a análise das reclamações que permitiu seguir o percurso dos procedimentos desencadeados pelas ouvidorias, promovendo estratégias de envolvimento e de disciplinamento dos usuários reclamantes e dos trabalhadores em saúde da instituição.

\section{O impacto da ação das ouvidorias hospitalares: envolvimento e disciplinamento}

O tema do envolvimento trata dos níveis de participação de cidadãos, de usuários e de trabalhadores nos planos e nas estratégias de desenvolvimento e em instituições. Foi colocado na pauta das discussões com maior vigor nos anos recentes, quando propostas alternativas de desenvolvimento foram feitas como resposta à crise dos anos 80 , em âmbito internacional e também no Brasil. A literatura sobre o envolvimento do cidadão enfatiza que esta é uma questão crucial para as democracias modernas. Como forma de envolvimento do cidadão, é importante ressaltar que serviços de ouvidoria foram encontrados na literatura internacional como uma possibilidade de o cidadão ser ouvido em suas reclamações acerca dos serviços prestados. Estes estudos foram realizados com o objetivo de explicar a participação do cidadão em programas sociais nas áreas de saúde, educação, previdência e urbanismo (Arnstein, 1969; Langton, 1979; Papadakis e Taylor-Gooby, 1987).

9 Helman especifica as diferentes culturas de gênero e o tratamento à saúde afirmando: Conforme descrito anteriormente neste livro, em quase todas as culturas a maior parte da atenção primária à saúde ocorre dentro da família e, no setor informal, os principais responsáveis pela assistência à saúde são, em geral, mulheres - mães e avós (Helman, 1994, p.144). Abel-Smith, a partir de que estudos haviam sido realizados em países em desenvolvimento, salienta a correlação entre investimento na educação e particularmente na educação feminina e incremento no cuidado à saúde (Abel-Smith 1994, p.55). 
No Brasil realizam-se discussões sobre participação na área da saúde (Campos, 1992; Cecílio, 1994; Cortes, 1995; Giacomini, 1992; Jacobi, 1992; Santos e Carvalho, 1992). O s estudos recentemente realizados pelo Laboratório de Planejamento e Administração (LAPA) da Unicamp debatem o tema, incluindo estudos em hospitais (Cecílio, 1994). Esses estudos, possibilitaram refletir e construir categorias de análise que permitam explicar o serviço de ouvidoria como estratégia de envolvimento de usuários e de trabalhadores em serviços de saúde ${ }^{10}$.

$\mathrm{Na}$ pesquisa, foi considerado que houve envolvimento quando, a partir do acolhimento das reclamações dos usuários, é tecida pela instituição, através da ouvidoria, uma rede de relacionamentos que implicam, em relação aos usuários, ouvir sua voz com o sentido de informação, aplacação ou consulta11. Estas tratam da acolhida ao usuário e da resposta institucional ao reclamante. Nestes casos, a instituição recebe o usuário, e suas queixas e opiniões são ouvidas.

Em relação aos trabalhadores em saúde, houve envolvimento quando a ouvidoria implementou estratégias que favoreceram sua integração passiva, adesão ou interação ${ }^{12} \mathrm{em}$ relação aos projetos institucionais que criaram este serviço.

10 As tipologias que permitiram pensar esta construção são originárias dos temas de participação do cidadão e de participação dos trabalhadores (a última tipologia, no caso das teorias da administração). Foram, porém, repensadas criticamente reconstruídas em termos de envolvimento de usuários e de trabalhadores, a partir de ouvidorias hospitalares. As categorias que tratam da participacão dos usuários foram elaboradas com base em Arnstein (1969), Cortes (1995) e Lee, Mills (1985). Em relação à participação dos trabalhadores em instituições, conta-se com tipologias genéricas, construídas pelas teorias da administração referidas por Melo (1984), Mendonça (1987) e Motta (1991).

11 A informação se efetiva quando a instituição absorve as reclamações como forma de ter ciência dos problemas e falhas, consideradas como eventuais. Essas falhas são explicadas ao usuário na tentativa de desestimulá-lo de registrar sua queixa. Informa, também, os usuários sobre seus direitos, responsabilidades e opcões em fazer uma reclamação. Q uando registradas, as mesmas são encaminhadas, masnem sempre são investigadas. Não há respostasao usuário. 0 envolvimento se realiza sob a forma de aplacação quando o usuário é ouvido, e as reclamações são investigadas. Porém o encaminhamento das investigações e das respostas é realizado de forma burocrática. Para as chefias são repassadas fotocópias das reclamações dos usuários, e solicitadas investigações. As respostas dos profissionais, à ouvidoria, tratam da justificativa dos procedimentos técnicos e do relato da aplicação de dispositivos legais disciplinares, no caso de condutas dos profissionais. Ao usuário, são repassadas, de forma burocrática, cópias das respostas das chefias e dos profissionais. 0 envolvimento é do tipo consulta quando a instituição assegura aos usuários o direito à voz. Neste caso, as reclamações e opiniões dos usuários são ouvidas e investigadas. Agindo com a intenção de consulta, a ouvidoria amplia realmente a voz do usuário, pois suas reclamações resultam em efetivas modificações nas formas de relacionamento, nas rotinas e procedimentos institucionais, quando constatada a falha no atendimento ao usuário. As reclamações são também levadas em conta nas decisões administrativas no que se refere à melhoria da prestação dos serviços ofertados pela instituição. Há resposta qualificada ao usuário, e esta consiste em informá-lo sobre as providências tomadas para solucionar os problemas detectados, reafirmando que o senviço de ouvidoria existe para defender seus direitos de cidadão.

$12 \mathrm{~A}$ integração se verifica quando os trabalhadores são envolvidos de forma passiva e não crítica nos objetivos da instituição, ao implantar uma ouvidoria hospitalar, conformando-se às normas e valores propostos pelo grupo que detém o poder. Esse nível de envolvimento ocorre quando os trabalhadores e chefias, dos hospitais pesquisados, apenas recebem uma comunicação, por parte da instituição, de que foi criada uma ouvidoria. O corre, também, quando os trabalhadores, e chefias, não cumprem as normas de investigação e respostas solicitadas pelo serviço de ouvidoria. 0 envolvimento se processa sob a forma de adesão quando os indivíduos unem-se aos objetivos institucionais com o sentimento de estarem engajados em uma ação estimulante. Nesse caso, os trabalhadores dos hospitais foram envolvidos na discussão de criação da ouvidoria e posteriormente aprovaram os objetivos propostos pela instituição. Ao aderir, respondem à ouvidoria, relatando as investigaçõese os procedimentos adotados. 0 envolvimento é do tipo interação quando os valores, sobre o significado e a importância de um serviço de ouvidoria, são compartilhados por todos. As reclamações são investigadas. Os problemas são discutidos e resolvidos. As respostas são qualificadas. 
O disciplinamento faz parte da rotina de uma instituição. O s serviços de ouvidoria possibilitam a aplicação de dispositivos disciplinares, pois são formas de intensificar a medicalização, ou seja, a reorganização dos hospitais em um espaço racionalizado. Medicalizar significa disciplinar, normatizar. Fortalecem uma ação disciplinadora, isto é, normatizadora das relações institucionais entre usuários e os serviços hospitalares, bem como entre os hospitais e os trabalhadores em saúde.

O estudo do disciplinamento nas instituições tem em Foucault (1996) um dos mais importantes referenciais teóricos. Ao estudar as formas de disciplinamento, Foucault (1990) destacou quatro tipos de tecnologias de si, que implicam formas de aprendizagem e de modificação dos indivíduos no sentido de aquisição de certas habilidades e atitudes. Essas tecnologias representam "matrizes da razão prática", constituindo-se em tecnologias de produção, de sistemas de signos, de poder e tecnologias de si propriamente ditas. Para esse autor, as quatro tecnologias quase nunca funcionariam separadas, embora estejam associadas a um tipo particular de dominação (Foucault, 1990).

Para verificar a relação entre serviços de ouvidoria em hospitais e disciplinamento, definiu-se como explicativa a noção de tecnologias de si, de Foucault, destacando particularmente as tecnologias de poder e as tecnologias de si. As noções de tecnologias de poder e de tecnologias de si permitem a compreensão dos processos de objetivação e de subjetivação dos sujeitos. Tecnologias de poder, isto é, objetivação, referem-se ao processo de conformação dos indivíduos aos fins e interesses das instituições. Tecnologias de si, isto é, subjetivação, compreendem a noção de identidade que os indivíduos estabelecem com os processos institucionais instaurados sobre seus corpos (Foucault, 1990).

Com relação ao serviço de ouvidoria hospitalar, considera-se que há poder disciplinar (Foucault, 1996) quando os hospitais possibilitam o disciplinamento das condutas de reclamantes e reclamados, bem como das rotinas e procedimentos institucionais tomados no sentido da resolu- 
ção dos problemas detectados. 0 disciplinamento dos reclamantes implica, portanto, no caso da ouvidoria, que o ouvidor oriente a conduta do reclamante quanto aos procedimentos a serem adotados em relação aos processos institucionais. Para disciplinar a conduta dos profissionais reclamados através das queixas registradas no serviço, o ouvidor e as chefias identificam o reclamado, orientam-no quanto a condutas específicas e aplicam as normas e dispositivos institucionais disciplinares, tais como advertência oral, escrita, suspensão, punição e demissão.

Embora não haja uma correspondência direta, relacionou-se a adoção da ouvidoria como forma de gerenciamento com as políticas sociais mais amplas. Q uando as micropolíticas denominadas ouvidorias estão em consonância com o projeto que propõe as idéias liberais de alteração do sistema de saúde, significam a criação de ouvidorias como forma de gerenciamento, com vistas a otimizar a relação custo/benefício da instituição no setor saúde, inserido numa lógica de mercado. 0 envolvimento é de clientes e trabalhadores, e o disciplinamento das relações institucionais é realizado para gerenciar o conflito entre instituição-cliente e instituiçãoprofissionais da saúde.

Se, ao contrário, a micropolítica ouvidoria está mais próxima do conteúdo do projeto reformador do sistema de saúde, então significa a criação de ouvidorias como forma de gerenciamento envolvendo usuários e trabaIhadores, porém dentro de outra lógica: oportunizando um canal que assegura aos usuários o direito de serem ouvidos e de terem voz. Há o disciplinamento das relações institucionais para que os profissionais se tornem permeáveis aos princípios que orientam as instituições hospitalares afinadas com a lógica epidemiológica do SUS. Essa lógica propõe medidas de democratização e de desburocratização entre as instituições de saúde e os usuários.

Os tipos de estratégia de envolvimento e de disciplinamento, desencadeadas em relação aos usuários reclamantes e aos trabalhadores reclamados, foram analisadas com base numa matriz teórica. Esta foi 
construída pela pesquisadora, a partir da literatura e da investigação dos indicadores de envolvimento e de disciplinamento dos sujeitos, após o registro de uma reclamação. Reunindo ouvidorias hospitalares, estratégias de envolvimento e de disciplinamento e com base na matriz teórica, foram definidos três tipos de ouvidorias de acordo com as estratégias promovidas: ineficiente, burocrática e eficaz.

Assim, considerou-se que a ouvidoria acolhe as reclamações como fonte de informação sobre os serviços prestados e envolve o usuário ao informá-lo de seus direitos. Envolve também os trabalhadores dos hospitais propiciando a sua integração passiva ao trabalho desenvolvido pelas ouvidorias hospitalares. Não disciplina os trabalhadores, ignorando o fato, motivo da reclamação. Agindo assim, caracteriza-se por ser uma ouvidoria ineficiente.

A ouvidoria recebe as reclamações, ainda, no sentido de envolver os usuários para aplacar os problemas institucionais. Em relação aos trabalhadores da instituição, envolve, desencadeando ações para promover sua adesão ao trabalho que a ouvidoria realiza. Neste caso, a ouvidoria atua de forma burocrática ${ }^{13}$.

Q uando a ouvidoria é criada num clima institucional, embasado na proposta reformadora, enfatiza os princípios de democratização institucional, impacta oportunizando a ampliação da voz e o efetivo envolvimento dos usuários, através da análise e das respostas as reclamações. Reforça ainda as estratégias de envolvimento e de disciplinamento internas. Envolvimento, no sentido de acolher as reclamações como forma de consulta, aos usuários, sobre os problemas e a qualidade do atendimento prestado pela instituição.

A ouvidoria desenvolve estratégias de interação dos trabalhadores com o programa implantado. Junto à administração, representa a voz dos usuários e estas pesam nas decisões que dizem respeito a situações de trabalho e

13 A atividade burocrática, em si mesma necessária para o funcionamento das instituições, torna-se um empecilho quando burocratizada em excesso. No caso das ouvidorias hospitalares, receber e encaminhar as reclamações foi considerada uma atividade negativamente burocrática quando aquelas foram repassadas mecanicamente, sem serem avaliadas e analisadas pelas ouvidorias. 
de conflito no espaço hospitalar, e sobre os objetivos sociais da instituição. Disciplinamento, no sentido de aplicar as normas institucionais cabíveis, ao investigar as reclamações. Neste caso, a ouvidoria é do tipo eficaz.

A tipologia de atuação de uma ouvidoria hospitalar foi construída com 0 intuito de compreender a realidade que é composta, efetivamente, da mistura destes três tipos: ineficiente, burocrática e eficaz. A concepção de que a realidade é composta pela mistura de vários tipos e não apenas de um tipo-ideal encontra-se amparada em W eber (1992) que assim o demonstrou ao analisar os tipos de ação social, bem como os tipos de dominação.

Analisando a realidade pesquisada constatou-se que as ouvidorias dos dois hospitais públicos promoveram estratégias de envolvimento e de disciplinamento cujas ações as caracterizaram como dois tipos de ouvidorias. A ouvidoria do Hospital Fêmina caracterizou-se por uma atuação do tipo burocrático e, em menor medida, por uma atuação ineficiente. Já a ouvidoria do Hospital de Clínicas atuou em maior proporção como uma ouvidoria ineficiente e, de forma menos acentuada, como uma ouvidoria burocrática.

Em relação ao disciplinamento dos usuários, não se observou a atuação ineficiente das duas ouvidorias. Isso porque não se limitaram a organizar o acolhimento das reclamações e orientar a conduta dos reclamantes. Encaminharam todas as reclamações recebidas para as devidas investigações. As estratégias que caracterizaram a atuação ineficiente das ouvidorias em relação aos usuários foram aquelas de envolvimento. Estas ocorreram de forma diferenciada em cada hospital.

No caso do Hospital Fêmina, a atuação ineficiente ficou explícita quando a ouvidoria considerou que a amostra dos problemas era suficiente, não sendo necessário ouvir todos os reclamantes. Agendou a entrevista, fazendo com que muitos não retornassem ao serviço. Mesmo recebendo elevado número de respostas (87\%), devolvidas pelas chefias com a investigação realizada, o serviço de ouvidoria do Hospital Fêmina não respondeu ao reclamante. As respostas ficaram arquivadas no setor. Este fato foi também evidenciado nas entrevistas quando todos os reclamantes afirmaram não ter recebido resposta das reclamações registradas. 
No caso do Hospital de Clínicas, a atuação ineficiente foi expressa pela qualidade da resposta ao usuário. Argumentando que sempre respondeu ao usuário, verificou-se, porém, que mais da metade das reclamações (58\%) não obtiveram respostas das chefias às solicitações do sistema. Este fato permitiu questionar a qualidade das respostas. Q ue respostas podem ser dadas aos usuários quando não houve respostas das chefias indicando que nada foi feito sobre as reclamações?

Em relação aos trabalhadores em saúde, constatou-se a atuação ineficiente das ouvidorias ao promover estratégias para envolvê-los. As estratégias de envolvimento caracterizaram-se, em sua maioria, pela integração passiva desses trabalhadores tanto na divulgação da ouvidoria, quando de sua implantação, como no decorrer de seu trabalho.

No caso do Hospital Fêmina, a divulgação foi feita seguindo a hierarquia do Hospital. A direção e o ouvidor comunicaram e justificaram às chefias, médicas ou não, a implantação do serviço. Comunicaram e justificaram também aos médicos. Os demais trabalhadores, porém, foram apenas informados pelas suas respectivas chefias. Considerou-se esta uma estratégia de integração passiva dos trabalhadores do Hospital Fêmina, exceção aos médicos e às chefias. No desenrolar de seu trabalho, porém, a integração passiva foi substituída pela adesão dos profissionais. Este aspecto foi evidenciado pelo grande percentual de respostas das chefias e dos profissionais às solicitações de investigação por parte do ouvidor.

No Hospital de Clínicas, não houve divulgação da implantação do sistema de ouvidoria. Somente alguns trabalhadores, os diretamente vinculados à recepção do Hospital foram integrados passivamente ao serem comunicados da nova forma de encaminhamento dos reclamantes. Nesse Hospital, a integração passiva dos trabalhadores foi verificada ainda no decorrer do trabalho do sistema, pois a maioria das chefias não respondeu a solicitações de investigação por parte do mesmo, demonstrando que não consideraram pertinentes as reclamações e não mudaram comportamentos. Assim sendo, em relação à promoção de estratégias de envolvimento 
dos trabalhadores em saúde, o sistema de ouvidoria do Hospital de Clínicas caracterizou-se como uma ouvidoria ineficiente.

Nos dois hospitais, verificou-se, no momento da pesquisa, a falta de divulgação sobre os objetivos, resultados e importância do trabalho da ouvidoria para os trabalhadores em saúde, com exceção das chefias.

A atuação de uma ouvidoria ineficiente, em relação ao disciplinamento dos trabalhadores em saúde reclamados, é o de não discipliná-los ignorando o fato, motivo da reclamação. Considerou-se que esta ação foi efetivada naqueles casos em que não havia registro de encaminhamento nem resposta das chefias nos arquivos das ouvidorias. No Hospital Fêmina, estes ocorreram em pequena proporção, 17\%, enquanto no Hospital de Clínicas, resultaram em mais da metade dos casos observados, $58 \%$.

O trabalho burocrático das ouvidorias caracterizou a atuação das mesmas nos dois hospitais investigados, porém de forma mais acentuada no Hospital Fêmina do que no Hospital de Clínicas. 0 trabalho burocrático foi constatado em diversas estratégias de envolvimento e de disciplinamento dos usuários e dos trabalhadores em saúde reclamados.

Em relação ao disciplinamento dos usuários, as duas ouvidorias atuaram predominantemente desta forma, pois, além de organizar o recebimento das reclamações, disciplinaram o encaminhamento e a investigação das mesmas. Atuaram ainda como ouvidorias burocráticas quando desencadearam estratégias de envolvimento dos usuários no sentido da aplacação da relação instituição-usuário, contemporizando os problemas institucionais.

No Hospital Fêmina, o agendamento da entrevista com o usuário reclamante foi um dos indicadores da estratégia de aplacação das relações institucionais. 0 agendamento foi pensado como uma forma de esfriar os ânimos do reclamante. Após o agendamento, o ouvidor recebeu os usuários por amostragem, característico da ouvidoria ineficiente, ouviu os reclamantes e explicou os fatos ocorridos, na tentativa de dissuadi-los de registrar sua reclamação. Quando a reclamação foi registrada, ela foi encaminhada, investigada e respondida pelas chefias. A qualidade destas respostas tam- 
bém indicou as estratégias de envolvimento do tipo aplacação. Estas justificaram o atendimento prestado com pareceres técnicos ou, nos casos nãomédicos, informaram a aplicação das medidas punitivas de rotina. Mesmo com o elevado número de respostas das chefias, o serviço de ouvidoria atuou de forma burocrática, pois as respostas ficaram arquivadas no serviço.

No caso do Hospital de Clínicas, não ocorreu o agendamento da entrevista com o usuário. 0 sistema de ouvidoria recebeu todos os reclamantes e os ouviu todos. O uviu-os porém através de um formulário e não de um ouvidor, indicativo do procedimento burocrático. Afirmando que sempre responde ao usuário, verificou-se que o envolvimento dos usuários, através da resposta, foi, além de ineficiente, burocrático. De fato, se ao dar um retorno ao reclamante do encaminhamento da queixa, o sistema de ouvidoria demonstrou uma preocupação com o usuário, foi também uma estratégia de envolvimento no sentido da aplacação. Isso porque houve um elevado número de reclamações sem resposta das chefias. Nesses casos, a secretária do GPE informava o fato ao usuário, na tentativa de comprovar que algo foi feito pela instituição, contemporizando a relação instituição-paciente.

Nos dois hospitais, em relação àquelas reclamações para as quais houve respostas, a atuação burocrática de aplacação também se verificou. Constatou-se que estas eram fotocópias das respostas das chefias. 0 teor das respostas eram as justificativas e a aplicação dos dispositivos legais. A qualidade das respostas das chefias satisfez a ouvidoria, porém o mesmo não ocorreu com o usuário reclamante.

No Hospital de Clínicas, conforme foi constatado através das entrevistas, a maioria dos usuários afirmaram ter recebido respostas. Q uestionaram, porém, a qualidade das mesmas, sentindo-se desrespeitados, pois estas contemporizavam a situação e não apontavam para a resolução do problema. Este procedimento caracterizou estratégias de envolvimento com objetivo de aplacação dos usuários reclamantes e foram típicos da atuação burocrática do sistema de ouvidoria daquele hospital. 
As estratégias para envolver os trabalhadores em seu trabalho também evidenciaram a atuação burocrática das duas ouvidorias. Encaminharam todas as reclamações acolhidas para investigação por parte das chefias dos serviços, setores e profissionais reclamados. Buscavam assim a adesão dos profissionais envolvidos na tarefa de acolher o reclamante, investigar e responder sua queixa. Este procedimento, porém, foi realizado de forma burocrática, pois as reclamações foram repassadas como papéis burocráticos.

A ouvidoria do Hospital Fêmina conseguiu envolver os profissionais, pois obteve respaldo institucional para suas solicitações. A grande maioria das chefias e profissionais aderiu ao trabalho realizado pelo serviço respondendo, ainda que burocraticamente. Este serviço atuou ainda de forma burocrática, buscando a adesão dos médicos, quando implantou 0 serviço. A estratégia de envolver os médicos procurando sua adesão, justificando a implantação do serviço antes de a mesma ocorrer, foi peculiar da ouvidoria do Hospital Fêmina e uma estratégia desencadeada particularmente em relação aos médicos.

A ouvidoria do Hospital de Clínicas não conseguiu a adesão das chefias e profissionais ao seu trabalho, pois menos da metade das chefias respondeu ao serviço. Não procurou também envolver os profissionais e as chefias nem na implantação nem no decorrer do trabalho realizado.

Em relação ao disciplinamento dos trabalhadores em saúde reclamados, as ouvidorias aplicaram os dispositivos legais comuns a toda instituição. Caracterizaram-se, porém, como burocráticas, pois apenas disciplinaram suas condutas, punindo-os sob as formas de advertência verbal, escrita, suspensão e demissão, e justificaram os procedimentos adotados. Pelo teor das respostas das chefias à ouvidoria, constatou-se que esses procedimentos foram coincidentes no Hospital Fêmina e no Hospital de Clínicas e foram aplicados sobre todos os trabalhadores reclamados. Não oportunizaram, entretanto, atividades de aprendizado de condutas sobre 0 atendimento mais qualificado ao usuário. 
O bservaram-se, contudo, formas diferenciadas de disciplinamento, de acordo com a hierarquia profissional existente no âmbito hospitalar. Verificou-se que ocorreu um maior número de justificativas, frente às demais formas de disciplinamento. O bservou-se também que as justificativas foram mais utilizadas pela área médica, sobre a qual recaiu maior número de reclamações.

A área administrativa utilizou mais o dispositivo de aplicar as normas punitivas. Pode-se argumentar que, como a adesão das chefias em responder ao serviço de ouvidoria, relatando as medidas tomadas em relação aos problemas e profissionais reclamados foi maior no Hospital Fêmina do que no Hospital de Clínicas, as estratégias de disciplinamento dos trabalhadores em saúde foram mais efetivas naquele Hospital do que neste.

\section{O s efeitos institucionais e sociais provocados pela ação das ouvidoriashospitalares}

Os efeitos desencadeados pelas ouvidorias hospitalares foram analisados a partir do impacto das mesmas, contribuindo para reforçar ou alterar a hegemonia de determinadas forças sociais e institucionais. Estes efeitos foram coincidentes nas duas instituições. 0 principal efeito social de implantação das ouvidorias hospitalares nos dois hospitais pesquisados foi a divulgação de algumas idéias e a implantação de estratégias relacionadas aos projetos sociais reformadores e liberais, na área da saúde. Como os dois hospitais não se posicionaram claramente por um dos projetos, agiram de forma ambígua em relação a ambos. Divulgaram idéias e agiram de acordo com princípios de ambos.

0 principal efeito institucional das ouvidorias hospitalares foi desencadear estratégias de envolvimento e de disciplinamento dos usuários reclamantes e dos trabalhadores em saúde reclamados. Considerando o tipo de atuação das ouvidorias, ineficiente e burocrático, argumenta-se que suas ações contribuíram para manter e não para alterar as relações 
institucionais vigentes, reforçando a hegemonia do poder médico-hospitalar. Contribuíram porém, em parte, para questionar esta estrutura de poder, pois intimaram chefias e profissionais a justificarem procedimentos e ações que desqualificavam o atendimento dos hospitais. No dois hospitais, a ouvidoria contribuiu para alterar, em parte, essas relações ao tornar as reclamações de usuários aceitas pelos médicos.

Se pode-se afirmar que as ouvidorias dos hospitais investigados promoveram estratégias que conduziram ao envolvimento e ao disciplinamento dos usuários reclamantes e dos trabalhadores em saúde das instituições, pode-se afirmar, porém, que estas não foram eficazes. Muitas vezes, um trabalho ou um profissional podem ser eficientes mas não, eficazes. Entende-se como eficácia o desejável do ponto de vista social (Pereira, 1995).

Quando se fala em eficácia, argumenta-se pelo tipo de ouvidoria que, em relação aos usuários, caracteriza-se pela acolhida da reclamação como uma forma de consulta. N este caso, a ouvidoria envolve ouvindo os usuários para solucionar os problemas institucionais. Incentiva-os a registrar sua reclamação e responde qualificadamente ao reclamante. A disciplina significa a solução dos problemas reclamados e não apenas disciplinar 0 recebimento, o encaminhamento e a investigação das reclamações.

Em relação aos trabalhadores em saúde, a ouvidoria eficaz promove a sua interação com a instituição. Q uando uma micropolítica institucional como o SO é pensada, a sua implantação é comunicada e discutida. No processo interno desencadeado pela ouvidoria o SO encaminha as reclamações e discute a solução de problemas. As chefias e os profissionais respondem qualificadamente. A disciplina do reclamado se efetiva sob a forma de treinamento e de processos educativos e não apenas sob a forma de punição ou justificativa dos problemas verificados. Estes últimos procedimentos são necessários para corrigir atos indesejados e fortalecem o comportamento ético por parte dos trabalhadores em saúde. Mas não são por si só suficientes. 
Nesta pesquisa foi argumentado que optar-se por ouvidorias, em serviços públicos, já é em si mesmo uma medida democrática e o que diferenciaria as ouvidorias umas das outras seria sua eficácia em ampliar ou diminuir a voz dos usuários, conforme a concepção institucional de ouvidoria e de atendimento em saúde, na qual ela está inserida.

Nos dois hospitais estudados, as ouvidorias não ampliaram a voz dos usuários de forma impactante. Isto se deve ao fato de não estarem claramente posicionadas pelo tipo de ouvidoria que queriam implantar. Ao acolher as reclamações, os hospitais envolveram, porém, os reclamantes oportunizando que, através deste canal, os usuários exercessem um maior controle público da qualidade dos serviços prestados, inclusive em hospitais, instituições em que, até então, achava-se que era impossível e indesejável a participação dos usuários ${ }^{14}$.

A concepção de uma ouvidoria eficaz apoiou-se na literatura sobre 0 tema, na qual é ela identificada com os direitos individuais, considerada um mecanismo democrático de controle da administração, de acesso à justiça e de defensoria popular. Apoiou-se também em experiências concretas como as da Inglaterra, Estados Unidos, Espanha, França, Canadá e Brasil (Amaral Fo, 1993, Asper y Valdés, 1990; Chrétien, 1983; Costa, 1991; Edling, 1988; Lyra, 1997; Papadakis e Taylor-Gooby, 1987; Langton, 1979; Levitt, 1980 e Rodriguez, 1982; entre outros).

Essa concepção foi também reforçada nas entrevistas. Como exemplo, cita-se que os respondentes manifestaram que deveria haver direitos e deveres iguais entre a instituição e seus profissionais e os usuários. No Hospital de Clínicas, por exemplo, quando o usuário não pode comparecer à consulta, é solicitada a gentileza que avise a instituição, no mínimo, com 24 horas de antecedência. U ma usuária que reclamou do não comparecimento do médico ao posto de trabalho, reivindicou o direito de ser comunicada de que a consulta não se realizaria, pois esta significava dis-

14 Inúmeras vezes essa participação foi questionada, quando se apresentava o projeto desta pesquisa. A dificuldade em aceitar a participação dos usuários, porém, ficou evidenciada nos dois hospitais, de forma típica, pela necessidade de desenvolver uma cultura de aceitação, por parte dos médicos, das reclamações de pacientes. 
pensa de seu trabalho. Neste caso, a falta do profissional não foi inesperada, mas resultante de ida a Congresso (HCPA-usuária, reclamação 53/98 e entrevista 25/99).

Entrevistados reclamados, dos dois hospitais, disseram que o ouvidor deveria, além de ouvir, percorrer os corredores, sentar nos bancos ao lado dos usuários, observar o atendimento prestado pela instituição. Sugeriram que o ouvidor fosse até os quartos de internação, perguntar aos usuários se havia problemas de atendimento. Insinuaram também que o ouvidor conversasse com os usuários quando recebesse a reclamação e, quando terminada a investigação, informasse aos mesmos os resultados conseguidos para a resolução do problema (HF e HCPA - usuário, entrevistas 25/99).

Foi sugerido ainda, por trabalhadores em saúde, que a ouvidoria fosse ocupada por vários profissionais, de áreas diferentes, que fizessem um trabalho mais coletivo. No Hospital de Clínicas, foi destacada a necessidade de uma infra-estrutura mais adequada para a realização de um efetivo trabalho de ouvidoria. Neste, entrevistados afirmaram que o trabalho da ouvidoria nunca foi valorizado adequadamente pelo contexto geral institucional.

Propostas de informatização da tarefa da ouvidoria foram também mencionadas por profissionais dos hospitais. Argumenta-se que a informatização auxiliaria, com certeza, porém, desde que 0 trabalho não permanecesse burocrático, à semelhança do que é hoje praticado. Que não servisse apenas para digitar ou escanear reclamações para um computador, sugerido como forma de manter a redação do paciente e facilitar o encaminhamento interno para as chefias. Q uando estas retornassem com a resposta, que não fossem apenas tiradas cópias das mesmas para serem encaminhadas aos reclamantes. Estes procedimentos já são realizados, sem o uso do computador.

U m envolvimento mais intenso dos profissionais das instituições foi sugerido, por alguns dos próprios trabalhadores em saúde reclamados, quando entrevistados. U ma das médicas ressaltou que sua participação na 
ouvidoria deu-se quando era chefe de serviço e foi solicitada a responder a queixas, porém, nunca fui escutar ninguém, nunca participei como ouvidora (HF-médica, entrevista 1/98).

Para que a ouvidoria possa atingir plenamente seus objetivos, 0 de ser um canal para ouvir a voz do cidadão, é necessário que tenha uma estrutura na qual a pessoa que é a responsável tenha respaldo institucional e não só da direção. Q ue a comunidade toda assuma a ouvidoria como um projeto institucional e a reclamação como uma questão eminentemente social e não apenas individual. Isso porque, como se afirmou anteriormente, as reclamações apontam para relações sociais muitas vezes imperceptíveis aos olhos de quem as experiencia. Agindo desta forma, as ouvidorias hospitalares amplificariam a voz dos usuários, propiciando uma melhoria da qualidade de atendimento nessas instituições.

\section{Considerações finais}

0 principal objetivo deste trabalho foi demonstrar que ouvidorias hospitalares conduzem ao envolvimento e ao disciplinamento de usuários e de trabalhadores em saúde. As conclusões a que se chegou foram possíveis devido à estratégia metodológica de comparar dois casos concretos. Observou-se que os objetivos, as ações e os resultados da atuação das ouvidorias nos dois hospitais investigados, embora diferenciando-se em intensidade, foram semelhantes nas duas instituições. Sendo ambas públicas, o tipo de hospital, com muitas ou poucas especialidades, universitário ou não, não foi decisivo a ponto de caracterizar ações diferenciadas das ouvidorias.

Após o estudo e a comparação da implantação de ouvidorias nos hospitais Hospital Fêmina e Hospital de Clínicas de Porto Alegre, podemse responder as questões e hipóteses que moveram este estudo. Confirmou-se a suposição dos motivos que induziram as instituições a criar ouvidorias. Estes estiveram, em primeiro lugar, mais diretamente relacionados à incorporação de novas ideologias e técnicas de gerenciamento por 
parte dos hospitais, das quais a ouvidoria é um exemplo. Assim, a melhoria da gestão administrativa e da prestação dos serviços foi objetivo e resultado alcançado com a implantação desse dispositivo.

O s objetivos de enfrentar a crise da área da saúde e a vinculação às propostas liberais ou reformadoras não estavam claramente expressos, embora pudessem ser também observados. 0 objetivo de tornar a gestão mais flexível, menos formal e burocrática ligaram os interesses institucionais de melhorar a gestão administrativa aos princípios propostos pela reforma do SUS. Porém, como não foi definida a intenção da ouvidoria em propiciar, também, a participação e o controle dos usuários sobre o serviço hospitalar, a vinculação a este princípio do SUS não se efetivou.

Com a pesquisa, ficou demonstrada a hipótese de que as ouvidorias são estratégias institucionais que conduzem ao envolvimento e ao disciplinamento dos usuários e dos trabalhadores em saúde dos hospitais. De fato as ouvidorias hospitalares promoveram internamente 0 envolvimento e 0 disciplinamento dos usuários e dos trabalhadores em saúde. Além disso, e aqui se encontra a particularidade deste estudo, com a pesquisa foi possível especificar os tipos de estratégias conduzidas pelas ouvidorias. Em relação aos usuários, elas consistiram em informação, aplacação e consulta. Em relação aos trabalhadores, elas foram de integração passiva, adesão e interação.

Foi possível também caracterizar três tipos da ouvidoria, tendo em vista a forma de sua atuação. Esses tipos aqui emergem com esta clareza, pois foram fruto de análise. $\mathrm{Na}$ verdade a ação real de uma ouvidoria hospitalar se aproxima mais ou menos destes tipos, ou o que é mais freqüente, mistura ações que caracterizam um ou vários deles (W eber, 1992). Assim, classificaram-se as ouvidorias em ineficientes, burocráticas e eficazes. A cada tipo relacionaram-se determinadas estratégias de disciplinamento e de envolvimento.

Verificou-se que as ouvidorias dos hospitais investigados atuaram de forma híbrida, não se caracterizando por um tipo puro, mas se diferenciaram pela intensidade de ações correspondentes a cada tipo de ouvidoria. 
Assim, a ouvidoria do Hospital Hospital Fêmina atuou principalmente de forma burocrática. Em relação a determinados casos, como o agendamento atuou também de forma ineficiente. Foi porém ineficiente principalmente em seu sistema de resposta ao reclamante. A ouvidoria do Hospital de Clínicas, ao contrário, atuou mais intensamente de forma ineficiente. Em relação às reclamações em que teve uma ação mais forte, esta se caracterizou como do tipo burocrático.

Uma conclusão derivada, daquelas já apresentadas, foi a de que se as ouvidorias estudadas atuaram propiciando a manutenção das relações institucionais vigentes. São porém, portadoras de um potencial de transformação. Chegou-se a essa conclusão comparando-se com o que seria uma ouvidoria eficaz. A ação deste tipo de ouvidoria implicaria principalmente ampliar a voz do usuário, promovendo maior eqüidade nas relações que envolvem o atendimento em saúde.

Salientam-se, finalmente, as possibilidades de generalização desta pesquisa. 0 tipo de estudo proposto permitiu uma generalização para as proposições teóricas e para práticas concretas dos dois hospitais investigados. Não pretende generalizar para o universo dos casos de ouvidoria no campo da saúde. Entretanto considerou-se fundamental contribuir com uma explicação sociológica que possibilite repensar a prática de ouvir o usuário reclamante, não só dos dois hospitais estudados, mas a prática de todos os envolvidos com a área da saúde em nosso país, principalmente dos que pautam sua ação por maior eqüidade nesta área.

\section{Referências bibliográficas}

ARNSTEIN, Sherry R. A ladder of citizen participation. Journal of American Institute Planners, 35 (3), 1969, p.216-224.

AU GUSTO, Maria H elena O .; CO STA, O lavo V. A saúde como direito so cial: algumas questões. Cadernos de Sociologia. N atureza, história e cultura. Repensando 0 social. Porto Alegre, UFRGS/PPGS, v. 4, número especial, 1993, p.113-118. 
Sociologias, Porto Alegre, ano 4, № 7, jan/jun 2002, p. 82-121

BARROS, Elizabeth. Política de saúde: a complexa tarefa de enxergar mudanças onde tudo parece permanência. Texto apresentado no 1 을 Congresso Brasileiro de Ciências Sociais em Saúde. Curitiba, fotocopiado, novembro de 1995.

BO URDIEU, Pierre. A economia das trocas simbólicas. 3.ed. São Paulo: Perspectiva, 1992.

BO URDIEU, Pierre. Lições de aula. Aula inaugural proferida no Collège de France. São Paulo: Ática, 1988.

BOURDIEU, Pierre. O poder simbólico. Rio de Janeiro: Bertrand, 1989.

BO U RDIEU, Pierre. Razões práticas: sobre a teoria da ação. Campinas, SP: Papirus, 1996.

BOU RDIEU, Pierre. Sociologia. O rg. Renato O rtiz . 2.ed. São Paulo: Ática, 1994.

BO U RD IEU, Pierre e PASSERO N, Jean-Claude. A reprodução: elementos para uma teoria do sistema de ensino. Rio de Janeiro: Francisco Alves, 1975.

BRASIL. Congresso. Lei 8.142 de 28 de dezembro de 1990 - Dispõe sobre a participação da comunidade na gestão do Sistema Ú nico de Saúde (SUS) e sobre as transferências intergovernamentais de recursos financeiros na área da saúde e dá outrasprovidências.

BRASIL. Constituição da República Federativa do Brasil. O liveira, Juarez de (org.). 11 ed. atual. e ampl. São Paulo: Saraiva, 1995.

CAMPOS, Gastão W. de Sousa. A saúde pública e a defesa da vida. São Paulo: HUCITEC, 1991.

CAM PO S, Gastão W. de Sousa. Coletânea de textos sobre a mudança em saúde. Não publicado.

CAM PO S, Gastão W. de Sousa. Reflexões sobre a proposta de gestão do sistema local de saúde. Cadernos da Nona. Brasília, v.1, p.39-42, 1992.

CARAPIN HEIRO, Graça. Saberes e poderes no hospital. U ma sociologia dos serviços hospitalares. 3 ed. Porto: Ed. Afrontamento Ltda, 1998. 
Sociologias, Porto Alegre, ano 4, № 7, jan/jun 2002, p. 82-121

CECÍLIO, Luiz Carlos de O liveira. Contribuições para uma teoria da mudança do setor público. In: CECíLIO, Luiz Carlos de O liveira. Inventando a mudança na saúde. São Paulo: HU CITEC, 1994, cap. 6.

CO RTES, Soraya M aria Vargas. U ser participation and reform of the brazilian health system: the case of Porto Alegre. The London School of Economics and Political Sciense, thesis submitted for a degree of D octor of Philosophy, 1995, p.25-66.

CZAPSKI, D. Juljan. Hospital como centro das ações de saúde. Cadernos da Nona. Brasília, v.2, 1992, p.155-158.

FO U CAULT, M ichel. A arqueologia do saber. 4.ed. Rio de Janeiro: Forense U niversitária, 1995.

FOU CAULT, Michel. M icrofísica do poder. 10 ed. Rio de Janeiro: Graal, 1992.

FO UCAULT, Michel. 0 nascimento da clínica. 4.ed. Rio de Janeiro: Forense Universitária, 1994.

FO UCAULT, Michel. Tecnologias del Yo y otros textos afines. Barcelona: Siglo Veintiuno, 1990.

FO U CAULT, Michel. Vigiar e punir. Petrópolis: Vozes, 1996.

GIACO M INI, Carlos Homero. A sociedade civil e a garantia do processo de reforma sanitária. Cadernos da N ona. Braślia, v. 2, 1992, p.109-112.

HAM BLETO N, Robin. Consumerism, decentralization and local democracy. Public Administration. London: The Royal Institute of Public Administration, v. 66, Summer 88,1988, p.125-147.

HIRSCHM AN, Albert. Saída, voz e lealdade. São Paulo: Ed. Perspectiva, 1973.

JACO BI, Pedro. Descentralização municipal e a participação dos cidadãos. Apontamento para debate. Cadernos da N ona. Brasília, v.2, 1992, p.113-120.

KADT, Emanuel de e TASCA, Renato. Promovendo a eqüidade: um novo enfoque com base no setor saúde. São Paulo-Salvador: Editora H U CITEC/Cooperação Italiana em Saúde, 1993. 
LANGTON, Stuart. Citizen participation in America: current reflections on the state of the art. -e- What is citizen participation? In: Citizen participation in America. EU A: I. Stuart Langton, 1979, p.1-24.

LEE, Kenneth, and MILLS, Anne. Policy-making and planning in the health sector. London: Croom H elm, 1985.

LUCCH ESI, Patrícia. Descentralização do financiamento e gestão da assistência à saúde no Brasil: retrospectiva 1990/1995 (versão preliminar). Coordenação Geral de Desenvolvimento e Avaliação de Serviços de Saúde, Ministério da Saúde, Brasília, fotocopiado, 1996.

LUZ, Madel T. N otas sobre as políticas de saúde no Brasil de transição democrática. Physis -Revista de Saúde Coletiva. Rio de Janeiro: IM S-UERJ/Relume Dumará, v.1, n.1, 1991, p.77-96.

M ELO, Marcus André B.C. de. Anatomia do fracasso: intermediação de interesses e a reforma das políticas sociais na Nova República. Dados -Revista de Ciências Sociais. Rio de Janeiro, v. 36, n.1, 1993, p.119-163.

MELO, Marlene Catarina de 0 . L. Processos de participação como meios nãoinstitucionalizados de regulação de conflitos. Revista Administração de Empresas, Rio de Janeiro, 24(4), out./dez., 1984, p.11-18.

M END O NÇA, Luis C. de. Participação na organização. U ma introdução aos seus fundamentos, conceitos e formas. São Paulo: Atlas, 1987.

M O TTA, Paulo Roberto. Gestão contemporânea: a ciência e a arte de ser dirigente. 2.ed. Rio de Janeiro: Record, 1991.

O LIVEIRA, Jaime A. de Araújo, TEIXEIRA, Sonia M. Fleury. (Im)previdência social: 60 anos de história da previdência no Brasil. Petrópolis: Vozes-Abrasco, 1986. p.269-301: Clímax da crise: transparência da estrutura de poder (1980-1983).

PAIM, Janilson Silva. As políticas de saúde e a conjuntura atual. Espaço para a Saúde, Curitiba, v. 1, n. 0, 1989, p.18-24.

PAPADAKIS, Elim, and TAYLOR-GOOBY, Peter. Consumer attitudes and participation in state welfare. Political Studies, XXXV, 1987, p.467-481. 
Sociologias, Porto Alegre, ano 4, no 7, jan/jun 2002, p. 82-121

PEREIRA, Luiza Helena. A busca da qualidade no Hospital Hospital Fêmina. Cadernos de Sociologia. Porto Alegre, UFRGS/PPGS, v. 7, 1995, p.189-207.

PEREIRA, Luiza Helena. O uvidoria hospitalar: envolvimento e disciplinamento de usuários e trabalhadores em saúde. No prelo. A ser publicado na Revista do Núcleo Interdisciplinar de Pesquisa em Saúde Coletiva-Nipesc, UFRGS, IFCH.

PIRES, D enise. Reestruturação produtiva e trabalho em saúde no Brasil. São Paulo: Annablume, 1998.

RIGON, Alessandro. O s círculos de controle de qualidade e sua utilização nos hospitais. Revista Hospitalar. Administração e Saúde. São Paulo, 17(5), 1993, p.244246.

SANTOS, Lenir dos e CARVALHO, Guido Ivan de. Das formas de controle social sobre as ações e os serviços de saúde. Cadernos da Nona. Braślia, v.2, 1992, p.121-126.

SASH KIN, M arshall e KISER, Kenneth J. Gestão da qualidade total na prática. Rio de Janeiro: Campus, 1994.

SEM IN ÁRIO discute a qualidade dos hospitais. Zero Hora. Porto Alegre, 3 nov. de 1993, p.34.

TEIXEIRA, Sonia M. Fleury. Política de saúde na transição conservadora. Saúde em Debate. São Paulo, CEBES, no 26, setembro, 1989, p.42-53.

TREVIZAN, Maria Auxiliadora. Enfermagem hospitalar. Administração \& burocracia. Brasília: Ed. U niversidade de Brasília, 1988.

W IN KLER, F. Consumerism in health care: beyond the supermarket model. Policy and Politics. September 1-8, 1987. In: HAMBLETO N, Robin. Consumerism, decentralization and local democracy. Public Administration. London, The Royal Institute of Public Administration, v. 66, Summer 88, 1988, p.125-147.

W EBER, Max. A ética protestante e o espírito do capitalismo. São Paulo: Pioneira, 1967. 
Sociologias, Porto Alegre, ano 4, no 7, jan/jun 2002, p. 82-121

\section{Resumo}

Este artigo apresenta os resultados da pesquisa sobre uma nova prática gerencial no campo da saúde: a criação de serviços de ouvidoria em hospitais públicos. Em Porto Alegre, dois hospitais públicos são exemplos da implantação desse tipo de serviço. $O$ texto situa o surgimento de ouvidorias no contexto da sociedade brasileira, especialmente focalizando a área da saúde e hospitais. A seguir discute 0 interesse dos hospitais em implantar ouvidorias e analisa as ouvidorias hospitalares como dispositivos que possibilitam a redefinição de relações institucionais implicando em envolvimento e em disciplinamento de usuários e de trabalhadores em saúde. Concluí afirmando que os principais efeitos institucionais e sociais provocados pela ação das ouvido rias hospitalares foram a divulgação dosprojetos liberal e reformador de alterações do sistema de saúde no Brasil e a redefinição de algumas das relações institucionais vigentes, sendo, porém, portadoras de um elevado potencial de democratização dessas relações.

Palavras-chave: ouvidoria hospitalar, relaçõesinstitucionais, saúde, políticas públicas. 